\title{
Short communication: Effects of meloxicam administration on protein metabolism and growth performance in transported Jersey calves
}

\author{
G. E. Chibisa, ${ }^{1}$ J. R. Vinyard, and A. H. Laarman \\ Department of Animal and Veterinary Science, University of Idaho, Moscow 83844
}

\begin{abstract}
Our objective was to investigate the effects of administering the nonsteroidal anti-inflammatory drug meloxicam (MEL) before transport on various indicators of protein metabolism and growth performance over the first $96 \mathrm{~h}$ after transport in Jersey calves. Calves (age $\pm \mathrm{SD} ; 2 \pm 1 \mathrm{~d}$ ) sourced from a commercial farm were randomly administered, at $1 \mathrm{mg} / \mathrm{kg}$ of body weight, either meloxicam (MEL; $\mathrm{n}=11$ ) or a whey protein placebo $(\mathrm{CON} ; \mathrm{n}=10)$ orally before transport to a calf facility $(669 \mathrm{~km} ; 8.5$-h road trip). Calves were weighed and rectal temperature was recorded before departure $(0 \mathrm{~h})$, on arrival $(8.5 \mathrm{~h})$, and $96 \mathrm{~h}$ after arrival. Blood was collected at the same time as calves were weighed, and samples were analyzed for total protein (0-h sample), cortisol (0- and 8.5-h samples), haptoglobin (0- and 96-h samples), and amino acids, 3-methylhistidine, and urea-N (96 h). Milk replacer (MR) intake was recorded on arrival and over the next $4 \mathrm{~d}$. Serum total protein concentration did not differ for CON and MEL calves. Plasma cortisol concentration was similar across treatments at $0 \mathrm{~h}$; however, it was lower for CON than for MEL calves at $8.5 \mathrm{~h}$. Although serum haptoglobin concentration tended to be greater for CON than MEL calves $96 \mathrm{~h}$ after transport, 3-methylhistidine and plasma urea-N concentrations did not differ across treatments. Plasma Asp, Asn, Glu, Lys, Met, Ser, and Trp were greater and plasma Arg, Gly, Pro, and Thr concentrations tended to be greater at $96 \mathrm{~h}$ after arrival for MEL compared with CON calves. Intake of MR and average daily gain were higher in MEL than in CON calves. In summary, although it had no effect on 3-methylhistidine or urea-N concentrations, administration of MEL before transport tended to reduce haptoglobin concentration, altered the amino acid profile, and was beneficial in preventing a decrease in MR intake and average daily gain in Jersey calves.
\end{abstract}

Received January 24, 2018.

Accepted August 13, 2018.

${ }^{1}$ Corresponding author: gchibisa@uidaho.edu
Key words: calf growth performance, meloxicam, protein metabolism, transportation

\section{Short Communication}

Changes in cellular metabolism, which are affected by age (Garrick and Baumgard, 2012), determine the severity of transport-related stress in cattle (Hulbert and Moisá, 2016). Calves < 4 wk of age tend to have higher rates of morbidity and mortality than older calves because of their naïve immune system, inability to effectively regulate body temperature, and the novelty of the experiences associated with transportation. In spite of this vulnerability, up to $10 \%$ of heifers and most bull calves are still transported within $48 \mathrm{~h}$ of birth in the US dairy sector (USDA-NAHMS, 2007). However, it is unclear at what age calves can be transported without severely perturbing cellular metabolism and, thus, compromising health, welfare, and productivity.

There are indications that transportation can have a negative effect on body protein metabolism. Besides the loss of up to 11\% of BW (Warriss, 1990), ADG can be suppressed for up to $28 \mathrm{~d}$ after transport (Cole et al., 1988). The blood concentration of haptoglobin, an acute phase protein (APP), also increases and peaks approximately $96 \mathrm{~h}$ after transport (Cooke et al., 2013; Guarnieri Filho et al., 2014), suggesting the presence of inflammation. However, information on the changes in cellular metabolism that occur and contribute to the negative outcomes of transportation, especially in calves $<1$ mo, remains scarce (Gifford et al., 2012).

Currently, there is considerable interest in the use of different strategies to attenuate transport-related stress in calves. One such strategy is the administration of nonsteroidal anti-inflammatory drugs (NSAID), including meloxicam (MEL), before transportation. To date, most studies have focused on older calves $(>6$ mo old), in which pre-transport administration of MEL reduced blood cortisol and haptoglobin concentrations (Guarnieri Filho et al., 2014; Van Engen et al., 2014). However, the effectiveness of NSAIDs in reducing the negative effects of transport-related stress on protein metabolism and growth efficiency in calves $<6$ mo old 
is unknown. Therefore, we evaluated the effect of administering MEL before transport of Jersey calves at $\leq 3 \mathrm{~d}$ of age on various measures of protein metabolism and growth performance within the first $96 \mathrm{~h}$ after transport. We hypothesized that administering MEL to calves before transportation mitigates stress-related changes in protein metabolism and prevents a decrease in ADG.

All procedures used in this study were approved by the Institutional Animal Care and Use Committee at the University of Idaho (protocol \# 2016-16). Briefly, 21 calves at $2 \pm 1 \mathrm{~d}$ of age (mean $\pm \mathrm{SD}$ ) were sourced from a commercial farm. Newborn calves were cared for according to the farm's management protocol. Briefly, calves were separated from their dams immediately after birth, and povidone iodine was used for navel dipping. Calves were then fed $6 \mathrm{~L}$ of maternal colostrum within $8 \mathrm{~h}$ of birth. Calves were also given a subcutaneous injection of trace minerals $(2 \mathrm{~mL}$; MultiMin USA, Fort Collins, CO) and transferred to the calf ranch approximately $8 \mathrm{~h}$ after birth. On the first day of our study, before transport $(0 \mathrm{~h})$, blood samples were collected from the jugular vein into Vacutainers (10 mL; Becton Dickinson, Franklin Lakes, NJ) containing either sodium heparin or a serum clot activator. Rectal temperature was recorded and all calves were weighed before random assignment to 1 of 2 treatments: (1) oral MEL $(1 \mathrm{mg} / \mathrm{kg}$ of BW; Carlsbad Technologies Inc., Carlsbad, CA; $\mathrm{n}=11)$; or (2) oral whey protein (1 mg/ $\mathrm{kg}$ of $\mathrm{BW}$, excipient used in the manufacture of meloxicam tablets; Nature's Best, Hauppauge, NY; control, CON; $\mathrm{n}=10$ ). Following administration of a bolus containing each treatment, calves were transported to our calf facility ( $669 \mathrm{~km}$; 8.5-h trip) in a commercial livestock trailer bedded with wood shavings. Calf blankets were used during transportation. Average trailer temperature and relative humidity during transport were logged every minute (RTH50 logger; FLIR Commercial Systems Inc., Nashua, NH) and were (mean \pm SD) 3.68 $\pm 2.300^{\circ} \mathrm{C}$ and $61.5 \pm 9.034 \%$, respectively. On arrival $(8.5 \mathrm{~h})$, calves were weighed, body temperature was recorded, and blood samples were collected. Calves were then housed in individual hutches bedded with wood shavings and fitted with infrared lamps. Maximum and minimum temperature $( \pm \mathrm{SD})$ over the 4 -d period following transportation were $-0.25 \pm 3.469$ and -7.28 $\pm 3.594^{\circ} \mathrm{C}$, respectively. Calves were fed up to $6 \mathrm{~L} / \mathrm{d}$ of milk replacer (MR; $150 \mathrm{~g}$ of DM/L; $26.1 \% \mathrm{CP}, 18.0 \%$ crude fat, $0.93 \% \mathrm{Ca}, 0.77 \% \mathrm{P}$, and $0.61 \% \mathrm{Na}$ on a $\mathrm{DM}$ basis; Calva Products LLC, Acampo, CA) twice daily (0730 and 1700h). At $96 \mathrm{~h}$ after arrival (approximately $1.5 \mathrm{~h}$ after the evening feeding), calves were weighed and rectal temperature was recorded. Blood samples were also collected and centrifuged $(1,000 \times g, 20 \mathrm{~min}$, $4^{\circ} \mathrm{C}$ ), and the harvested plasma and serum were frozen $\left(-80^{\circ} \mathrm{C}\right)$. Commercial kits were used to analyze serum total protein (0 h samples; Bioo Scientific, Austin, TX), plasma cortisol (0- and 8.5-h samples; Arbor Assays, Ann Arbor, MI), and serum haptoglobin (0- and 96-h samples; Innovative Research, Novi, MI). The intraassay coefficients of variation were $4.2,10.8$, and $5.5 \%$ for total protein, cortisol, and haptoglobin, respectively. Plasma samples (96 h samples) were also analyzed for AA, urea-N, and 3-methylhistidine at the University of Missouri-Columbia's Agricultural Experiment Station Chemical Laboratory using the procedures of Deyl et al. (1986) and Fekkes (1996).

All data were analyzed as a completely randomized design using the MIXED procedure of SAS (SAS Institute Inc., Cary, NC). The statistical model included the fixed effects of treatment, time, and treatment $\times$ time interaction, and the random effect of calf. The variancecovariance error structure with the lowest Akaike's and Bayesian information criteria was used for the temporal data. A covariate term (0-h measurements) was added to the model for cortisol, haptoglobin, BW, and body temperature data. Residual distributions were evaluated for normality and homoscedasticity, and total protein, cortisol, haptoglobin, Trp, His, urea-N, and 3 -methylhistidine data were log-transformed to meet the criteria for normality and homoscedasticity. The effect of treatment on mortality was analyzed using the Fisher Exact test. Data are presented as least squares means. Significance was declared at $P<0.05$ and trends at $0.05 \leq P \leq 0.10$.

Although the concentration of plasma cortisol, a widely used physiological biomarker of stress, was similar across treatments before transportation, it was lower $(P<0.01)$ for CON than for MEL calves after transportation (Table 1). Guarnieri Filho et al. (2014) did not observe changes in plasma cortisol in weaned calves ( $>6$ mo old) after administering MEL before a 24 -h road trip $(1,440 \mathrm{~km})$. On the other hand, Van Engen et al. (2014) reported a tendency for a decrease in cortisol concentration in MEL compared with CON calves after a road trip $(1,316 \mathrm{~km} ; 16 \mathrm{~h})$ and an inverse relationship between plasma MEL and cortisol concentrations. This was taken to be suggestive of MEL downregulating the activation of the hypothalamicpituitary-adrenal (HPA) axis and, thus, reducing the severity of the stress response. Numerous factors, including the loading and unloading processes and trailer conditions, influence the stress response (Trunkfield and Broom, 1990), which could account for the discrepancies between our study and those of Guarnieri Filho et al. (2014) and Van Engen et al. (2014). 
Table 1. Blood cortisol and haptoglobin concentrations, rectal temperature, milk replacer intake, BW, ADG, and feed efficiency in calves administered a whey protein placebo $(\mathrm{CON})$ or meloxicam (MEL) before transport (8.5-h trip)

\begin{tabular}{|c|c|c|c|c|c|c|}
\hline \multirow[b]{2}{*}{ Variable } & \multicolumn{2}{|c|}{ Treatment } & \multirow[b]{2}{*}{ SEM } & \multicolumn{3}{|c|}{$P$-value } \\
\hline & $\mathrm{CON}$ & MEL & & Treatment & Time & $\begin{array}{c}\text { Treatment } \\
\times \text { Time }\end{array}$ \\
\hline Cortisol, $\mathrm{ng} / \mathrm{mL}$ & & & & 0.06 & 0.02 & $<0.01$ \\
\hline At departure & 32.7 & 29.2 & 3.4 & & & \\
\hline $96 \mathrm{~h}$ after arrival & 14.5 & 31.4 & 3.4 & & & \\
\hline Haptoglobin, $\mu \mathrm{g} / \mathrm{mL}$ & & & & 0.09 & 0.45 & 0.06 \\
\hline At departure & 9.7 & 11.2 & 8.6 & & & \\
\hline $96 \mathrm{~h}$ after arrival & 33.0 & 1.11 & 8.6 & & & \\
\hline Rectal temperature, ${ }^{\circ} \mathrm{C}$ & & & & 0.93 & $<0.01$ & 0.31 \\
\hline At departure & 38.0 & 38.1 & 0.2 & & & \\
\hline On arrival & 38.3 & 38.0 & 0.2 & & & \\
\hline $96 \mathrm{~h}$ after arrival & 39.0 & 39.1 & 0.2 & & & \\
\hline Intake, $\mathrm{kg}$ of $\mathrm{DM} / \mathrm{d}$ & & & & $<0.01$ & $<0.01$ & 0.32 \\
\hline On arrival & 0.471 & 0.582 & 0.035 & & & \\
\hline Day after arrival & & & & & & \\
\hline 1 & 0.393 & 0.697 & 0.059 & & & \\
\hline 2 & 0.702 & 0.817 & 0.052 & & & \\
\hline 3 & 0.757 & 0.889 & 0.038 & & & \\
\hline 4 & 0.819 & 0.900 & 0.038 & & & \\
\hline $\mathrm{BW}, \mathrm{kg}$ & & & & 0.07 & $<0.01$ & 0.05 \\
\hline At departure & 28.3 & 28.5 & 0.4 & & & \\
\hline On arrival & 27.5 & 27.9 & 0.4 & & & \\
\hline $96 \mathrm{~h}$ after arrival & 32.8 & 34.8 & 0.4 & & & \\
\hline $\mathrm{ADG}^{1}$ & & & & & & \\
\hline $\mathrm{kg} / \mathrm{d}$ & 1.34 & 1.82 & 0.13 & 0.02 & - & - \\
\hline $\mathrm{kg} / \mathrm{kg}$ of milk replacer intake & 2.06 & 2.16 & 0.20 & 0.56 & - & - \\
\hline
\end{tabular}

${ }^{1}$ Days 1 to 4 after arrival.

Transportation can result in increased hepatic synthesis of positive APP, including haptoglobin and ceruloplasmin. Systemic haptoglobin has been shown (Cooke et al., 2013; Guarnieri Filho et al., 2014) to increase and peak approximately $96 \mathrm{~h}$ after transport in feeder calves. In our study, serum haptoglobin concentration tended to be lower $(P=0.09)$ in MEL than in CON calves (Table 1). The classification of calves based on the measured haptoglobin concentration yielded the following: $>10 \mu \mathrm{g} / \mathrm{mL}$ at $0 \mathrm{~h}=3 \mathrm{CON}$ versus $3 \mathrm{MEL}$, $>10 \mu \mathrm{g} / \mathrm{mL}$ at $96 \mathrm{~h}=3 \mathrm{CON}$ versus $0 \mathrm{MEL}$, remained under $10 \mu \mathrm{g} / \mathrm{mL}=6 \mathrm{CON}$ versus $8 \mathrm{MEL}$, remained over $10 \mu \mathrm{g} / \mathrm{mL}=2 \mathrm{CON}$ versus $0 \mathrm{MEL}$, changed from over to under $10 \mu \mathrm{g} / \mathrm{mL}=1 \mathrm{CON}$ versus $3 \mathrm{MEL}$, and changed from under to over $10 \mu \mathrm{g} / \mathrm{mL}=0 \mathrm{CON}$ versus 0 MEL. Therefore, the differences in the number of calves whose concentration was $>10 \mu \mathrm{g} / \mathrm{mL}$ at $0 \mathrm{~h}$ but decreased below that threshold at $96 \mathrm{~h}$ might explain the tendency for a decrease in haptoglobin concentration in MEL than in CON calves. Guarnieri Filho et al. (2014) also noted a decrease in plasma haptoglobin and ceruloplasmin concentrations 3 to 5 d after transport, which is suggestive of MEL having an effect on the APP response. This modulatory effect could be through cyclooxygenase, an enzyme that regulates the synthesis of eicosanoids involved in the pro-inflammatory response, which MEL inhibits (Lees et al., 2004).

Araujo et al. (2010) reported a negative correlation (r $\leq-0.50$ ) between haptoglobin concentration and ADG in transported feeder cattle. Either a decrease in feed intake or an upregulation of skeletal muscle wasting to provide the additional AA required for APP synthesis could account for the decrease in ADG (Gifford et al., 2012). In our study, besides being greater $(P<0.01)$ from d 2 to 4 compared with d 1 after arrival, MR intake was also greater $(P<0.01)$ for MEL than for CON calves. In addition, we detected a tendency $(P$ $=0.05)$ for a treatment $\times$ time interaction for BW; although similar at departure and arrival across treatments, BW was greater for MEL than for CON calves at $96 \mathrm{~h}$ after transport. Therefore, this accounts for the greater ADG in MEL than in CON calves, which is in agreement with observations made by Guarnieri Filho et al. (2014). However, it is important to note that the ADG and feed efficiency in our study were high, which could be because we weighed the calves approximately $1.5 \mathrm{~h}$ after feeding for the $96-\mathrm{h}$ sampling time. Besides causing changes in MR intake, MEL administration could have reduced skeletal muscle wasting, thereby partly accounting for the difference in ADG. However, 
Table 2. Blood total protein, 3-methylhistidine, urea-N, and AA concentration in calves administered a whey protein placebo $(\mathrm{CON})$ or meloxicam (MEL) before transport (8.5-h trip)

\begin{tabular}{|c|c|c|c|c|}
\hline \multirow[b]{2}{*}{ Variable } & \multicolumn{2}{|c|}{ Treatment } & \multirow[b]{2}{*}{ SEM } & \multirow[b]{2}{*}{$P$-value } \\
\hline & $\mathrm{CON}$ & MEL & & \\
\hline Total protein, ${ }^{1} \mathrm{~g} / \mathrm{dL}$ & 6.52 & 6.91 & 0.30 & 0.40 \\
\hline 3-Methylhistidine, ${ }^{2} \mu \mathrm{g} / \mathrm{mL}$ & 0.400 & 0.379 & 0.048 & 0.83 \\
\hline Urea-N ${ }^{2} \mu \mathrm{g} / \mathrm{mL}$ & 138 & 110 & 17 & 0.39 \\
\hline \multicolumn{5}{|l|}{$\mathrm{AA},{ }^{2} \mu \mathrm{g} / \mathrm{mL}$} \\
\hline $\begin{array}{l}\text { Ala } \\
\text { Arg }\end{array}$ & $\begin{array}{l}34.6 \\
25.8\end{array}$ & $\begin{array}{l}39.0 \\
34.2\end{array}$ & $\begin{array}{l}2.4 \\
3.3\end{array}$ & $\begin{array}{l}0.20 \\
0.09\end{array}$ \\
\hline Asn & 7.21 & 9.57 & 0.71 & 0.03 \\
\hline Asp & 1.11 & 1.48 & 0.08 & $<0.01$ \\
\hline Cit & 12.8 & 17.7 & 1.0 & $<0.01$ \\
\hline Glu & 15.0 & 19.4 & 1.4 & 0.04 \\
\hline Gln & 31.2 & 33.4 & 2.7 & 0.57 \\
\hline Gly & 25.2 & 31.0 & 2.1 & 0.07 \\
\hline His & 7.70 & 6.68 & 1.17 & 0.63 \\
\hline Ile & 19.2 & 21.7 & 2.0 & 0.38 \\
\hline Leu & 26.4 & 28.6 & 3.0 & 0.60 \\
\hline Lys & 31.3 & 42.3 & 3.5 & 0.04 \\
\hline Met & 8.1 & 11.1 & 0.7 & $<0.01$ \\
\hline Orn & 7.79 & 8.90 & 0.96 & 0.42 \\
\hline Phe & 5.47 & 5.95 & 0.77 & 0.67 \\
\hline Pro & 12.7 & 16.3 & 1.3 & 0.07 \\
\hline Ser & 12.2 & 16.2 & 0.9 & $<0.01$ \\
\hline Thr & 31.2 & 39.8 & 3.3 & 0.09 \\
\hline Trp & 12.1 & 15.5 & 0.9 & 0.02 \\
\hline Tyr & 7.33 & 8.52 & 0.90 & 0.36 \\
\hline Val & 28.9 & 29.5 & 2.9 & 0.88 \\
\hline
\end{tabular}

concentrations of plasma 3-methylhistidine, an indirect indicator of skeletal muscle protein breakdown (Harris and Milne, 1981), did not differ $(P=0.83)$ across treatments (Table 2). Similarly, we found no differences $(P=0.39)$ in plasma urea- $\mathrm{N}$ concentration. To the contrary, Warriss et al. (1995) noted an increase in blood urea-N concentration in transported cattle, which was attributed to a potential increase in muscle wasting and thus hepatic AA oxidation. Therefore, it is plausible that the metabolic demand for AA to support various stress response-related functions, including haptoglobin synthesis, was not sufficiently higher in CON than in MEL calves to result in differences in the rate of skeletal muscle protein breakdown in our study.

In addition to dietary supply, systemic AA concentration is determined by the processes of protein synthesis and breakdown, and de novo AA synthesis and oxidation (Waggoner et al., 2009; Hoskin et al., 2016). Plasma concentrations of Asn, Asp, Cit, Glu, Lys, Met, Ser, and Trp were greater $(P \leq 0.04)$, and those of Arg, Gly, Pro, and Thr tended to be greater $(0.07 \leq P \leq 0.09)$ in MEL than in CON calves at $96 \mathrm{~h}$ after transport (Table 2). However, the concentrations of Ala, Gln, His, Ile, Leu, Orn, Phe, Tyr, and Val did not differ $(P \geq 0.20)$ across treatments. The higher MR intake for MEL compared with CON calves could account for the greater plasma AA concentrations in our study. Although information for transported calves is still lacking, pro-inflammatory and APP reactions induced in cattle and sheep using an endotoxin challenge resulted in a decrease in the plasma concentration of several AA, including Asn, Glu, Lys, and Phe (Waggoner et al., 2009; Hoskin et al., 2016). This is attributed to increased use of systemic AA to support various stress response-related functions, including hepatic APP synthesis and gluconeogenesis. Therefore, a lower metabolic demand for AA to support the stress response could have resulted in greater plasma concentrations of Asn, Arg, Asp, Cit, Glu, Gly, Lys, Met, Pro, Ser, Thr, and Trp in MEL compared with CON calves. However, concentrations of 3-methylhistidine and plasma urea-N did not differ across treatments, and it is unlikely that this potential difference in metabolic AA demand was substantial enough to cause appreciable changes in the rate of skeletal muscle protein degradation. In a study with rats, administration of ibuprofen, another NSAID, reduced age-related muscle wasting (Rieu et al., 2009). This was attributed to a potential decrease in the rate of protein synthesis in skeletal muscle, which we did not quantify in our study. The greater $\mathrm{ADG}$ we observed for MEL than CON calves suggests the use of a greater amount of AA for protein 
synthesis, which could lower plasma AA concentration. Because MEL calves consumed a greater amount of MR than CON calves, this could have prevented a protein synthesis-driven decrease in plasma AA concentration. However, there is a need for better characterization of the changes that might occur in the rates of protein synthesis and degradation in various organs and tissues in transported calves.

Ambient temperature during transportation and housing has a major effect on the severity of the stress response, especially for calves $<7 \mathrm{~d}$ old, which have limited capacity to thermo-regulate (Hulbert and Moisá, 2016). In addition to compromising growth, heat or cold stress increases mortality and morbidity rates in calves. Our study was conducted in winter and we used calf blankets during transportation to comply with institutional animal care stipulations. We also used heat lamps and wood shaving for bedding in hutches. Therefore, although it was higher $(P<0.01)$ at $96 \mathrm{~h}$ compared with 0 and $8.5 \mathrm{~h}$ relative to transportation, rectal temperature was within the normal physiological range of 38.1 to $39.2^{\circ} \mathrm{C}$ (Moran, 2002; Piccione et al., 2003). Two CON calves and 1 MEL calf had elevated temperature $24 \mathrm{~h}$ after transport and were treated with an antibiotic. A greater number of CON compared with MEL (6 vs. $0 ; P=0.03$ ) calves died within the first 10 $\mathrm{d}$ after arrival. All calves that died had signs of scours and one was positive for fecal shedding of Salmonella. However, because not all dead calves were necropsied, we cannot rule out other causes of death besides gastrointestinal infection. However, these adverse health events and mortalities highlight the need for transport stress-alleviating strategies for calves $<7 \mathrm{~d}$ old, which still have a nascent immune system and limited ability to thermo-regulate.

In conclusion, administering MEL to Jersey calves $(\leq 3 \mathrm{~d})$ before hauling can alleviate the negative effects of transportation on MR intake and $\mathrm{ADG}$, perhaps by altering protein metabolism as reflected by the changes in systemic haptoglobin and AA concentration $96 \mathrm{~h}$ after transport. However, further studies are needed to evaluate the effects of transportation and use of NSAIDs on molecular regulation of protein synthesis and degradation in key organs including the liver and skeletal muscle in calves. Adequately characterizing the effects of transportation on metabolic function will enable the development of effective strategies to mitigate the stress response.

\section{ACKNOWLEDGMENTS}

This work was supported by the USDA National Institute of Food and Agriculture (Washington, DC;
Hatch project 1010553). The authors thank D. McCurdy, C. Myers, G. Santillanes, B. Rogers, and M. Meyers (Department of Animal and Veterinary Science, University of Idaho, Moscow) for assisting in the husbandry of the calves and collection of data and samples for analysis.

\section{REFERENCES}

Araujo, D. B., R. F. Cooke, G. R. Hansen, C. R. Staples, and J. D. Arthington. 2010. Effects of rumen-protected polyunsaturated fatty acid supplementation on performance and physiological responses of growing cattle after transportation and feedlot entry. J. Anim. Sci. 88:4120-4132. https://doi.org/10.2527/jas.2009-2684.

Cole, N. A., T. H. Camp, L. D. Rowe, D. G. Stevens, and D. P. Hutcheson. 1988. Effect of transport stress in feeder calves. Am. J. Vet. Res. 49:179-183.

Cooke, R. F., B. I. Cappellozza, T. A. Guarnieri Filho, and D. W. Bohnert. 2013. Effects of flunixin meglumine administration on physiological and performance responses of transported feeder cattle. J. Anim. Sci. 91:5500-5506. https://doi.org/10.2527/jas.2013 $-6336$.

Deyl, Z., J. Hyanek, and M. Horakova. 1986. Profiling of amino acids in body fluids and tissues by means of liquid chromatography. J. Chromatogr. 379:177-250. https://doi.org/10.1016/S0378 -4347(00)80685-4.

Fekkes, D. 1996. State-of-the-art of high-performance liquid chromatographic analysis of amino acids in physiological samples. J. Chromatogr. B Biomed. Appl. 682:3-22. https://doi.org/10.1016/0378 -4347(96)00057-6.

Garrick, D. J., and L. H. Baumgard. 2012. Invited review: Genomic analysis of data from physiological studies. J. Dairy Sci. 95:499 507. https://doi.org/10.3168/jds.2011-4970.

Gifford, C. A., B. P. Holland, R. L. Mills, C. L. Maxwell, J. K. Farney, S. J. Terrill, D. L. Step, C. J. Richards, L. O. Burciaga Robles, and C. R. Krehbiel. 2012. Growth and development symposium: Impacts of inflammation on cattle growth and carcass merit. J. Anim. Sci. 90:1438-1451. https://doi.org/10.2527/jas.2011-4846.

Guarnieri Filho, T. A., R. F. Cooke, B. I. Cappellozza, M. M. Reis, R. S. Marques, and D. W. Bohnert. 2014. Effects of meloxicam administration on physiological and performance responses of transported feeder cattle. J. Anim. Sci. 92:4137-4144. https://doi.org/ 10.2527/jas.2014-7783.

Harris, C. I., and G. Milne. 1981. The urinary excretion of $\mathrm{N}(\tau)$ methyl histidine by cattle: Validation as an index of muscle protein breakdown. Br. J. Nutr. 45:411-422. https://doi.org/10.1079/ BJN19810116.

Hoskin, S. O., D. M. Bremner, G. Holtrop, and G. E. Lobley. 2016. Responses in whole-body amino acid kinetics to an acute, sub-clinical endotoxin challenge in lambs. Br. J. Nutr. 115:576-584. https:// doi.org/10.1017/S0007114515004894.

Hulbert, L. E., and S. J. Moisá. 2016. Stress, immunity, and the management of calves. J. Dairy Sci. 99:3199-3216. https://doi.org/10 $.3168 /$ jds.2015-10198.

Lees, P., M. F. Landoni, J. Giraudel, and P. L. Toutain. 2004. Pharmacodynamics and pharmacokinetics of nonsteroidal anti-inflammatory drugs in species of veterinary interest. J. Vet. Pharmacol. Ther. 27:479-490. https://doi.org/10.1111/j.1365-2885.2004.00617 .x.

Moran, J. 2002. Calf Rearing-A Practical Guide. 2nd ed. Landlinks Press, Collingwood, Australia.

Piccione, G., G. Caola, and R. Refinetti. 2003. Daily and estrous rhythmicity of body temperature in domestic cattle. BMC Physiol. 3:7. https://doi.org/10.1186/1472-6793-3-7.

Rieu, I., H. Magne, I. Savary-Auzeloux, J. Averous, C. Bos, M. A. Peyron, L. Combaret, and D. Dardevet. 2009. Reduction of low grade inflammation restores blunting of postprandial muscle anabolism 
and limits sarcopenia in old rats. J. Physiol. 587:5483-5492. https: //doi.org/10.1113/jphysiol.2009.178319.

Trunkfield, H. R., and D. M. Broom. 1990. The welfare of calves during handling and transport. Appl. Anim. Behav. Sci. 28:135-152. https://doi.org/10.1016/0168-1591(90)90050-N.

USDA-NAHMS (National Animal Health Monitoring System). 2007. Dairy 2007: Heifer calf health and management practices on U.S. dairy operations. USDA Animal and Plant Health Inspection Service, Veterinary Services, Ft. Collins, CO. Accessed Nov. 21 , 2016. https://www.aphis.usda.gov/animal_health/nahms/dairy/ downloads/dairy07/Dairy07_ir_CalfHealth.pdf.

Van Engen, N. K., M. L. Stock, T. Engelken, R. C. Vann, L. W. Wulf, L. A. Karriker, W. D. Busby, J. Lakritz, A. J. Carpenter, B. J. Bradford, W. H. Hsu, C. Wang, and J. F. Coetzee. 2014. Impact of oral meloxicam on circulating physiological biomarkers of stress and inflammation in beef steers after long-distance transportation. J. Anim. Sci. 92:498-510. https://doi.org/10.2527/jas.2013-6857.

Waggoner, J. W., C. A. Löest, J. L. Turner, C. P. Mathis, and D. M. Hallford. 2009. Effects of dietary protein and bacterial lipopolysaccharide infusion on nitrogen metabolism and hormonal responses of growing beef steers. J. Anim. Sci. 87:3656-3668. https://doi .org/10.2527/jas.2009-2011.

Warriss, P. D. 1990. The handling of cattle pre-slaughter and its effects on carcass meat quality. Appl. Anim. Behav. Sci. 28:171-186. https://doi.org/10.1016/0168-1591(90)90052-F.

Warriss, P. D. S. N. Brown, T. G. Knowles, S. C. Kestin, J. E. Edwards, S. K. Dolan, and A. J. Phillips. 1995. Effect on cattle of transport by road for up to 15 hours. Vet. Rec. 136:319-323. https: //doi.org/10.1136/vr.136.13.319. 